\title{
Anterior tarsal tunnel syndrome: an atypical involvement in primary neural leprosy
}

Síndrome do túnel do tarso anterior: um comprometimento atípico na hanseníase neural primária Diogo Fernandes dos SANTOS ${ }^{1,2}$, Raquel Campos PEREIRA'1, Isabela Maria Bernardes GOULART1,2

Anterior tarsal tunnel syndrome is a compressive neuropathy of the deep peroneal nerve in the anterior ankle at the extensor retinaculum. Several factors may be the cause of anterior tarsal tunnel syndrome: trauma, fractures, subluxation, abnormal posture, edema and others, although there is no association with infectious diseases ${ }^{1,2}$.
We report on a 37-year-old woman, with a family history ofleprosy, with positive serological (ELISA anti-PGL 1) and molecular (real-time PCR/qPCR of slit-skin smear) tests, without skin lesions. Electroneuromyography showed a demyelinating sensory-motor deep peroneal nerve impairment in the ankle, with secondary axonal loss. Peripheral sensory nerve biopsy, confirmed by molecular methods, revealed an atypical primary neural leprosy, ${ }^{3,4}$

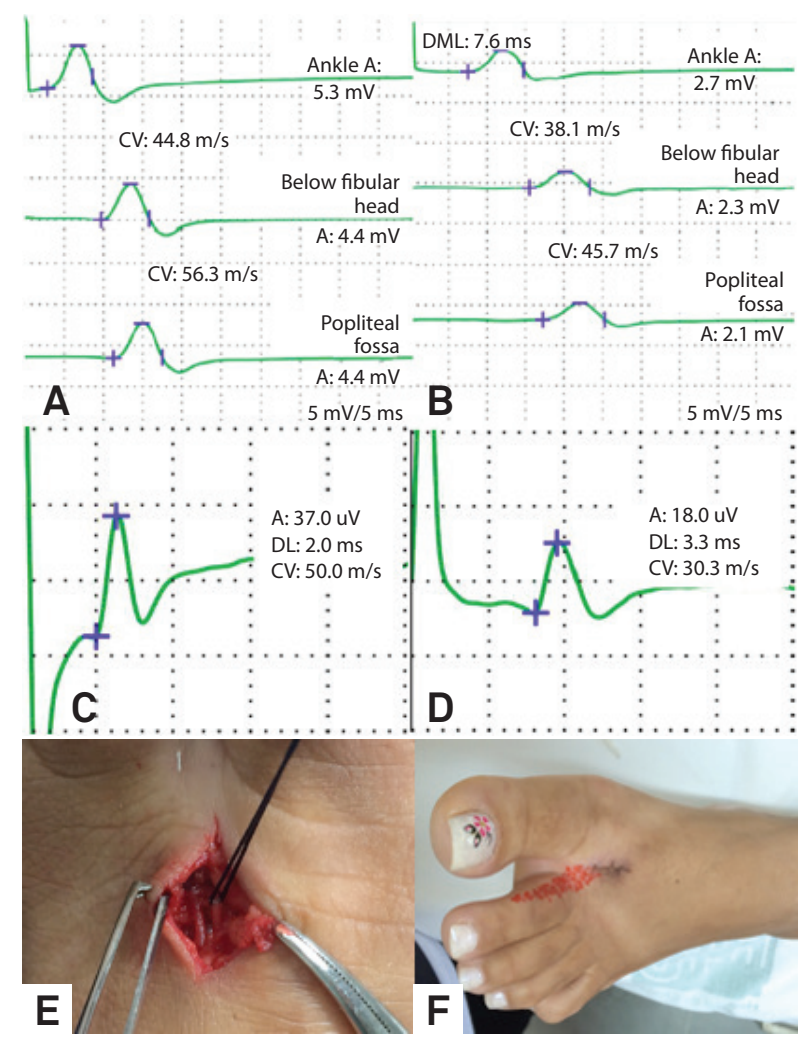

Figure. Motor conduction study demonstrating normal parameters in the right peroneal nerve (A), but with a focal myelin impairment of the left peroneal nerve (B) in the anterior ankle (evident prolongation of distal motor latency). A sensory conduction study demonstrated normal parameters on the right deep peroneal nerve (C), but with reduction of the conduction velocity and the amplitude of the sensory action potential on the left deep peroneal nerve (D). Biopsy of the peripheral nerve - sensory branch of the deep peroneal nerve (E). Area of hypoesthesia corresponding with the deep peroneal nerve (F).

\footnotetext{
${ }^{1}$ Universidade Federal de Uberlândia, Hospital das Clínicas, Centro de Referência Nacional em Dermatologia Sanitária e Hanseníase, Uberlândia MG, Brasil; ${ }^{2}$ Universidade Federal de Uberlândia, Faculdade de Medicina, Programa de Pós-Graduação em Ciências da Saúde, Uberlândia MG, Brasil.

Diogo Fernandes dos Santos (iD https://orcid.org/0000-0002-3807-9987; Raquel Campos Pereira iD https://orcid.org/0000-0001-7836-5745; Isabela Maria Bernardes Goulart (iD) https://orcid.org/0000-0002-3284-1037

Correspondence: Diogo Fernandes dos Santos; Departamento de Clínica Médica, Faculdade de Medicina, UFU; Av. Pará, 1720, Bloco 2H - Campus Umuarama; 38400-902 Uberlândia MG, Brasil; E-mail: diogofsan@yahoo.com.br

Conflict of interest: There is no conflict of interest to declare

Received 24 November 2018; Received in final form 16 February 2019; Accepted 01 May 2019.
} 


\section{References}

1. Logullo F, Ganino C, Lupidi F, Perozzi C, Di Bella P, Provinciali L. Anterior tarsal tunnel syndrome: a misunderstood and a misleading entrapment neuropathy. Neurol Sci. 2014 May;35(5):773-5. https://doi.org/10.1007/s10072-013-1601-8.

2. DiDomenico LA, Masternick EB. Anterior tarsal tunnel syndrome. Clin Podiatr Med Surg. 2006 Jul;23(3):611-20. https://doi.org/10.1016/j.cpm.2006.04.007.

3. Santos DFD, Mendonça MR, Antunes DE, Sabino EPF, Pereira RC, Goulart LR et al. Revisiting primary neural leprosy: Clinical, serological, molecular, and neurophysiological aspects. PLoS

Negl Trop Dis 2017 Nov;11(11):e0006086.

https://doi.org/10.1371/journal.pntd.0006086

4. Santos DFD, Mendonça MR, Antunes DE, Sabino EPF,

Pereira RC, Goulart LR, et al. Molecular, immunological and neurophysiological evaluations for early diagnosis of neuralimpairment in seropositive leprosy

household contacts. PLoS Negl Trop Dis 2018 May;12(5):e0006494. https://doi.org/10.1371/journal.pntd.0006494 